\title{
PHYSICO - CHEMICAL CHARACTERISTICS OF BIO - OIL FROM NANNOCHLOROPSIS SP AND TETRASELMIS AS A SUSTAINABLE ENERGY SOURCE
}

\author{
Arif Hidayat \\ Chemical Engineering Department, Faculty of Industrial Technology, Universitas Islam Indonesia \\ Jl. Kaliurang km 14,5, Sleman, Yogyakarta 55584 \\ Email : arif.hidayat@uii.ac.id
}

\begin{abstract}
ABSTRAK
Mikroalga saat ini dipromosikan sebagai bahan baku biofuel generasi ketiga yang ideal karena laju pertumbuhannya yang cepat, kemampuan fiksasi $\mathrm{CO}_{2}$ dan kapasitas produksi lipida yang tinggi; Mereka juga tidak bersaing dengan makanan atau tanaman pakan, dan bisa diproduksi dilahan yang tidak dapat dipanen. Mikroalga mampu menghasilkan 15-300 kali lebih banyak minyak untuk produksi biodiesel daripada tanaman tradisional berdasarkan area. Selanjutnya dibandingkan dengan tanaman konvensional yang biasanya dipanen sekali atau dua kali setahun, mikroalga memiliki siklus panen yang sangat singkat, sehingga menghasilkan banyak atau panen terus menerus dengan hasil panen yang meningkat secara signifikan. Tujuan dari penelitian ini adalah untuk mengevaluasi sifat fisikokimia dan komposisi minyak yang diambil dari dua jenis bubuk mikroalga kering, Nannochloropsis sp. Dan Tetraselmis sp. Bio-oil diekstraksi dari sampel alga kering. Ekstraksi bio-oil dilakukan dengan ekstraksi pelarut dengan mencampur pelarut kloroform-metanol. Komposisi minyak alga ditentukan dengan analisis kromatografi gas. Hasilnya menunjukkan 20-29\% jumlah minyak disemua sampel alga. Tetraselmis sp. Menunjukkan jumlah minyak maksimal 28,1\%.
\end{abstract}

Kata Kunci : Bio-Oil, Mikroalga, Tetraselmis Sp, Nannochloropsis Sp.

\section{INTRODUCTION}

The basic sources of energy are petroleum, natural gas, coal, hydroelectrical and nuclear. The need of energy is increasing continuously due to the increase in population and industrialization. The continued use of petroleum sourced fuels is now widely recognized as unsustainable because of the depletion supplies and the contribution of these fuels to the accumulation of carbon dioxide in the environment leading to increase of global warming. In the last ten years, many studies have been conducted on biofuels for substituting fossil fuels and reduce the greenhouse gas emission.

The third generation biofuels derived from microalgae are considered to be a viable alternative energy resource that is devoid of the major drawbacks associated with first and second generation biofuels (Chisti, 2007; Nigam and Singh, 2010 ; Li et al., 2008). Microalgae are able to produce 15-300 times more oil for biodiesel production than traditional crops on an area basis. Furthermore compared with conventional crop plants which are usually harvested once or twice a year, microalgae have a very short harvesting cycle (1- 10 days depending on the process), allowing multiple or continuous harvests with significantly increased yields.

Microalgae are organisms that grow in aquatic environments and use light and carbon dioxide $\left(\mathrm{CO}_{2}\right)$ to create biomass. Microalgae are photosynthetic microorganisms that are able to rapidly generate biomass from solar energy, $\mathrm{CO}_{2}$ and nutrients in bodies of water. Microalgae are tiny (measured in micrometers), unicellular algae that normally grow in suspension within a body of water. This biomass consists of important primary metabolites such as sugars, oils and lipids, for which 
Table 1. Oil Yields Based on Crop Type (Chisti 2007)

\begin{tabular}{c|c}
\hline Crop & Oil yield (gallons / acre) \\
\hline Corn & 18 \\
Soybeans & 48 \\
Canola & 127 \\
Jatropha & 202 \\
Coconut & 287 \\
Oil Palm & 636 \\
Microalgae & $6283-14641$ \\
\hline
\end{tabular}

process path-ways exist for the production of high-value products including human and animal feed supplements, transport fuels, industrial chemicals and pharmaceuticals.

Because the bulk of the natural oil made by microalgae is in the form of tricylglycerol - which is the right kind of oil for producing biodiesel - microalgae are the exclusive focus in the algae-to-biofuel arena. Microalgae grow very quickly compared to terrestrial crops. They commonly double in size every 24 hours. During the peak growth phase, some microalgae can double every 3.5 hours (Chisti 2007). Oil content of microalgae is usually between 20 percent and 50 percent (dry weight, table 1), while some strains can reach as high as 80 percent (Metting 1996 ; Spolaore et al. 2006).

Compared with terrestrial crops which take a season to grow and only contain a maximum of about 5 percent dry weight of oil microalgae grow quickly and contain high oil content (Chisti 2007). This is why microalgae are the focus in the algae-tobiofuel arena. Table 1 lists the potential yields of oil produced by various crops and compares these values to oil yields from an open pond growing microalgae.

Many researcher using different organic solvent to get high oil yield on extraction technique of dry algae. In a study by Lee et al. (1998), the performance of five different organic solvent mixtures in extracting lipids from bead-beaten Botryococcus braunii cells was compared.
From the experiments it can be concluded that chloroform/methanol obtained the highest final total lipid yield at $\sim 0.29 \mathrm{~g} / \mathrm{g}$ dried microalgal biomass. On the other hand, dichloroethane-based organic solvent mixtures (dichloroethane / methanol and dichloroethane / ethanol), previously recommended for lipid extraction from the green algae Cladofora, were found to have limited efficacies when applied to $B$. braunii.

Hexane / isopropanol ( $3 / 2 \mathrm{v} / \mathrm{v})$ mixture has been suggested as a low-toxicity substitute to chloroform / methanol system (Halim et al., 2011). The mixture works in a similar fashion with chloroform / methanol system. Upon biphasic separation, the upper organic phase (hexane with some isopropanol) contains most of the lipids (both neutral and polar) while the lower aqueous phase (water with some isopropanol) contains most of the non-lipids (proteins and carbohydrates). When evaluated for microalgal lipid extraction, hexane / isopropanol mixture was found to be more selective towards neutral lipids compared to chloroform / methanol system (Guckert et al., 1988; Lee et al., 1998; Nagle and Lemke, 1990). The objective of this study was to evaluate the physicochemical properties and the composition of the oil extracted from two types of dried microalgal powder, Nannochloropsis sp. and Tetra selmis $s p$.This is essential for evaluating the possibility of using the oil for biodiesel production. 


\section{METHODOLOGY}

\subsection{Dry Algae Pretreatment}

Two types of dried microalgal powder, Nannochloropsis sp. and Tetra selmis chui, were used in the experiment. Dried microalgal powder were obtained from Balai Besar Budidaya Air Payau (BBBAP) Situbondo, East Java, Indonesia. Methanol and chloroform pro analytic was purchased form Merck.Dry algae was pretreated by microwave using a classical microwave oven. The output microwave power is variable up to $1000 \mathrm{~W}$ and the frequency of $2450 \mathrm{MHz}$. The power applied is $800 \mathrm{~W} .10$ grams of dried microalgae were weighed. Microalgae sample was loaded inside a Pyrex bowl. Then, it was placed into the microwave oven to be treated for 15 minutes.

\subsection{Oil Extraction}

Dried microalgal biomass were extracted by mixing chloroform - methanol $(1: 1 \mathrm{v} / \mathrm{v})$ in a proportion of $1: 1$ using a slightly modified version of Bligh and Dyer's method (1959). Extraction set up mainly consists of a three necked round bottom flask $(250 \mathrm{ml})$. The neck in the middle of the flask was connected to a reflux condenser, a thermometer was placed in one of the two side necks and the third neck was used for taking samples during the extraction process. The flask was submerged in a temperature controlled water bath with magnetic stirrer. Oil extraction was performed for 4 hours. The oil solutions were filtered and then subjected to distillation using rotary evaporator to release the chloroform - methanol solution.

\subsection{Oil Analysis}

Oil yield of each microalgal were measured and compared. Fourier transform infrared spectroscopy (FTIR) analysis was carried out with this microalgal oil. The FTIR analysis is used to detect the chemical bonds of compounds. Analysis of oil composition was performed using a Gas Chromatograph Mass Spectrophotometer (GC-MS Shimadzu GC-2010, Japan).

\section{RESULTS AND DISCUSSION 3.1. Effect of Temperature}

The effect of temperature on the algal oil extraction yield was examined over the range of $35-65^{\circ} \mathrm{C}$ from microalgae biomass (Figure1). The oil yield was found to be enhanced with the rise in the temperature. This is due to the increase in the dissolution capacity of the solvent system. The rise in the temperature from $35^{\circ}$ to $55^{\circ} \mathrm{C}$ leads to increase in the yield from $17 \%$ to $27 \%$. At $55^{\circ} \mathrm{C}$, highest oil extraction yield of $27 \%$ was obtained at optimum conditions of solvent - to - solid ratio of 5:1 and $500 \mathrm{rpm}$ stirrer speed for 4 hours. It was observed that at optimum temperature of $55^{\circ} \mathrm{C}$, the solubility of the solvent was found to be increased with increase in diffusion rate.Effect of Extraction Time

The extraction time is an important parameter for oil yield. It helps in deciding the optimum residence time required for the extraction process. In this study, the effect of time on the oil extraction was investigated with different time intervals varying from 2 to 8 hours (Figure2). The results showed that oil extraction yield increases with increase in time. The extraction was established with the optimum condition of stirrer speed of 500 rpm, temperature at $55^{\circ} \mathrm{C}$ and solvent-tosolid ratio of $5: 1$. After 8 hours of extraction, the oil extraction yield was obtained as $26.5 \%$. 


\subsection{Effect of Solvent-to-Solid Ratio}

The effect of solvent-to-solid ratio on the oil extraction is shown in figure 3 . The influence of solvent-to-solid ratio from 1:1 to $6: 1$ on oil extraction was studied by maintaining all other parameters at optimum conditions. As the solvent-to-solid ratio increased from $1: 1$ to $6: 1$, the oil yield was found to be increased from $17 \%$ to $28.1 \%$.
The trend was continued with increase in solvent-to-solid ratio up to 6:1. Further increase in solvent - to - solid ratio above 6:1 did not show much improvement in the oil extraction. Therefore the solvent-to-solid ratio of $6: 1(\mathrm{v} / \mathrm{w})$ was found to be an optimum ratio for the further study.

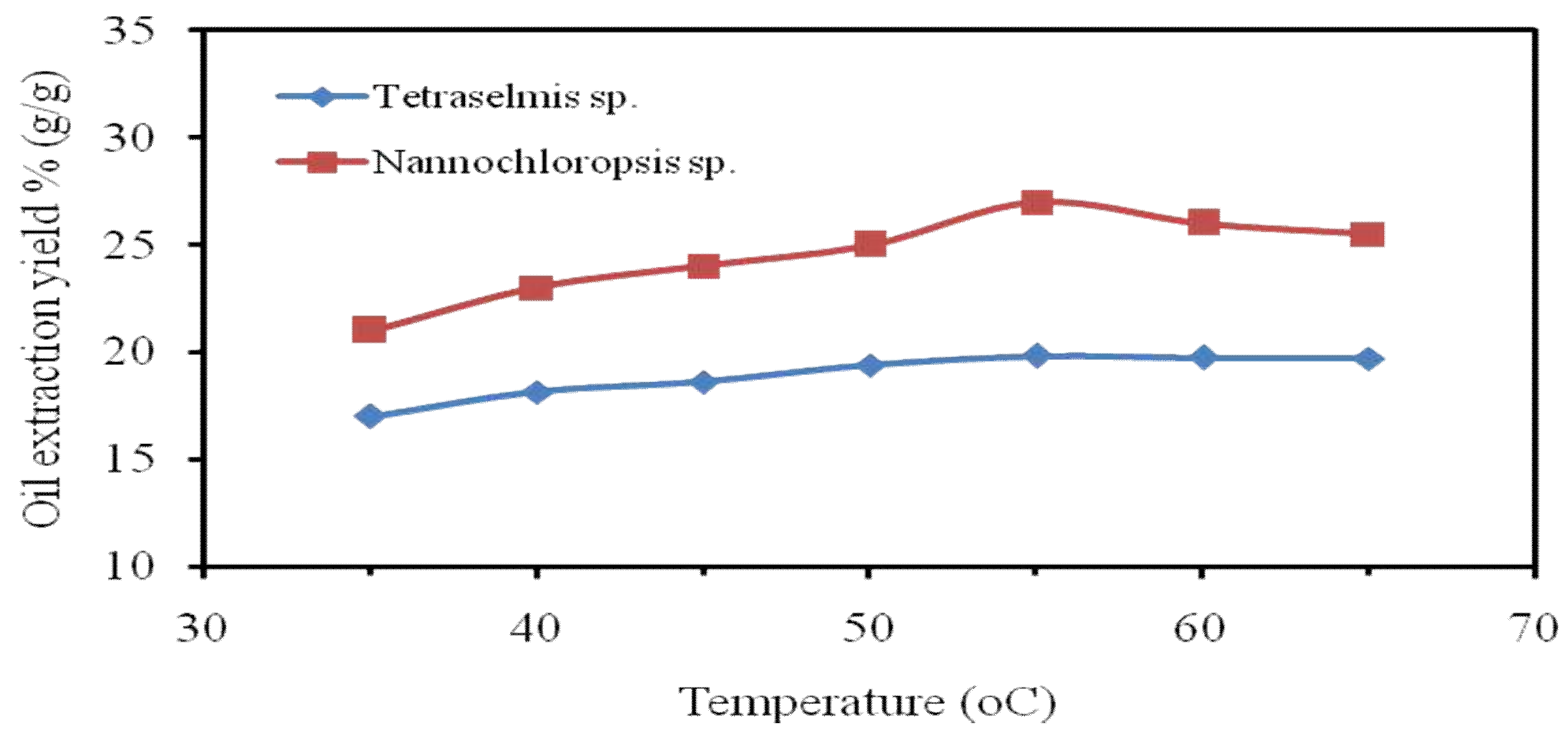

Figure1. Effect of Extraction Temperature on Oil Extraction.

(Conditions : Stirrer Speed: 500 Rpm; Extraction Time: 4 Hours; Solvent-To-Solid Ratio: 5:1)

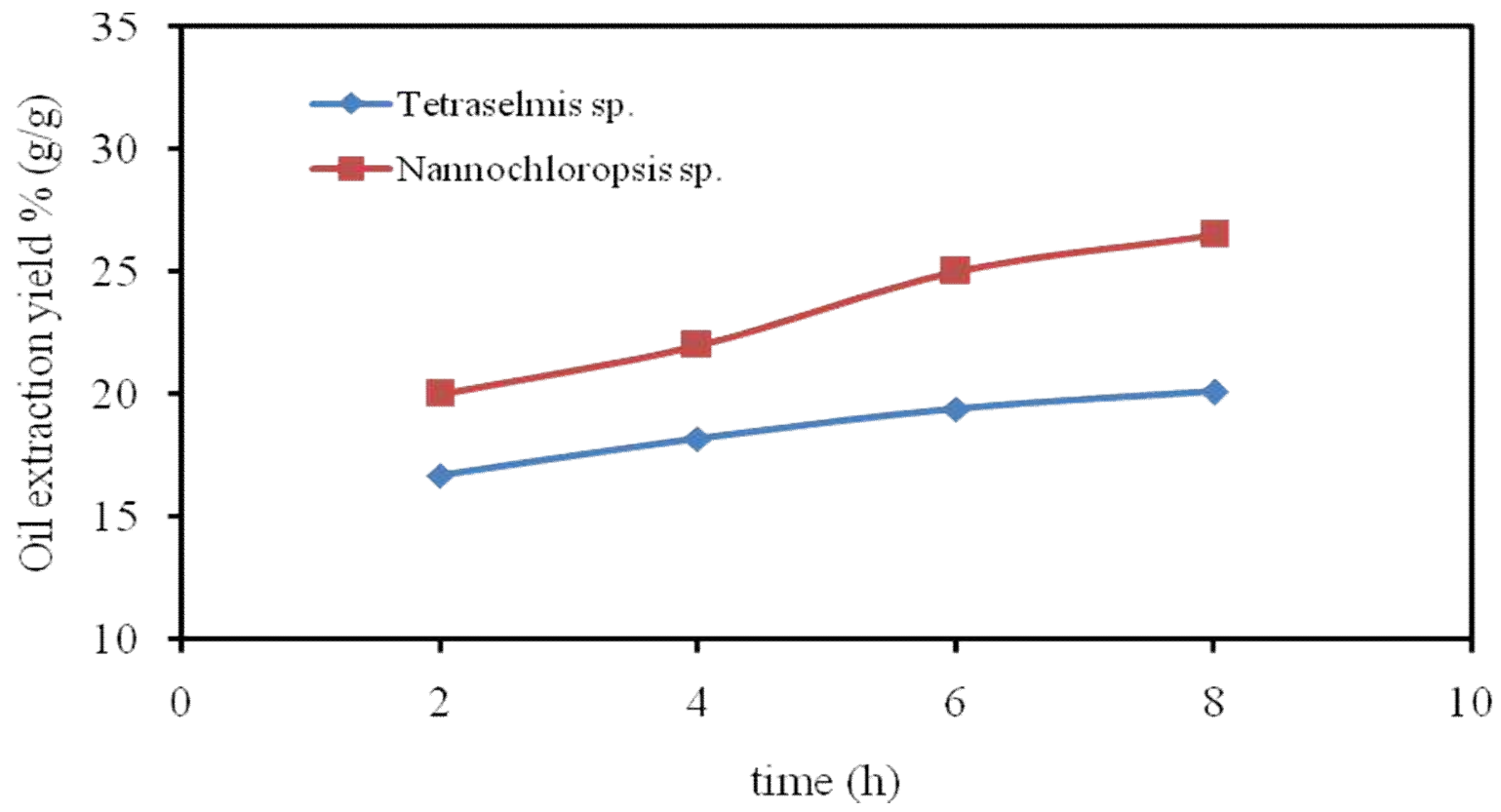

Figure 2. Effect of Extraction Time on Oil Extraction.

(Conditions: Stirrer Speed: $500 \mathrm{rpm}$, Temperature: $55^{\circ} \mathrm{C}$; Solvent-to-Solid Ratio: 5:1) 


\subsection{The Physicochemical Properties of Algae Oil}

Generally, the FTIR spectra show five important peaks explaining the stretching, bending and double bond absorption of the oil samples. We observe that the absorption peaks are the same for all five oil samples where the $\mathrm{C}-\mathrm{H}$ stretching absorption occurs at wavelength $2971 \mathrm{~cm}^{-1}$. This peak appears strong in all microalgae oil samples as shown in figure 4 . Two alkanes peaks which is attributed the bending absorption of methylene $\left(\mathrm{CH}_{2}\right)$ and methyl $\left(\mathrm{CH}_{3}\right)$ groups appears at 1464 and $1375 \mathrm{~cm}-1$, respectively. Two peaks observed at 1764 and $1159 \mathrm{~cm}-1$ are due to stretching absorption of aldehyde $(\mathrm{C}=\mathrm{O})$ and esters $(\mathrm{C}-\mathrm{O})$ respectively. All these peaks are appeared in all microalgae oil samples. However, the stretching absorption of $(\mathrm{O}-\mathrm{H})$ at $3346 \mathrm{~cm}^{-1}$ is strong in all samples. This stretching $(\mathrm{O}-\mathrm{H})$ absorption is intermolecular hydrogen bonding for water.
Further analysis of the bio-oil using GC-MS presents a more detailed characterisation of the liquid fraction in this work. The major peaks detected by GC-MS have been isolated, numbered sequentially and presented according to retention time in table 2. The total 30 components presented in table 2 were identified by the GC-MS software library. The sample exhibits a range of fatty acids, alkanes, alkenes, amides, aldehydes, terpenes, pyrrolidinines, phytol and phenols. Prominent amongst these are nitrogen containing compounds, most likely due to the high protein content and chlorophylls found in the algae, correlating with FT-IR results. According to GC-MS, aromatic hydrocarbons, including benzene and toluene, are detected and a significant number of compounds register in the $\mathrm{C} 16-$ C20 bracket, including methyl esters. The length of the carbon chain in the bio-oil was in the range of $\mathrm{C} 7-\mathrm{C} 17$, and the oil boiling point was in a range of $100-300^{\circ} \mathrm{C}$.

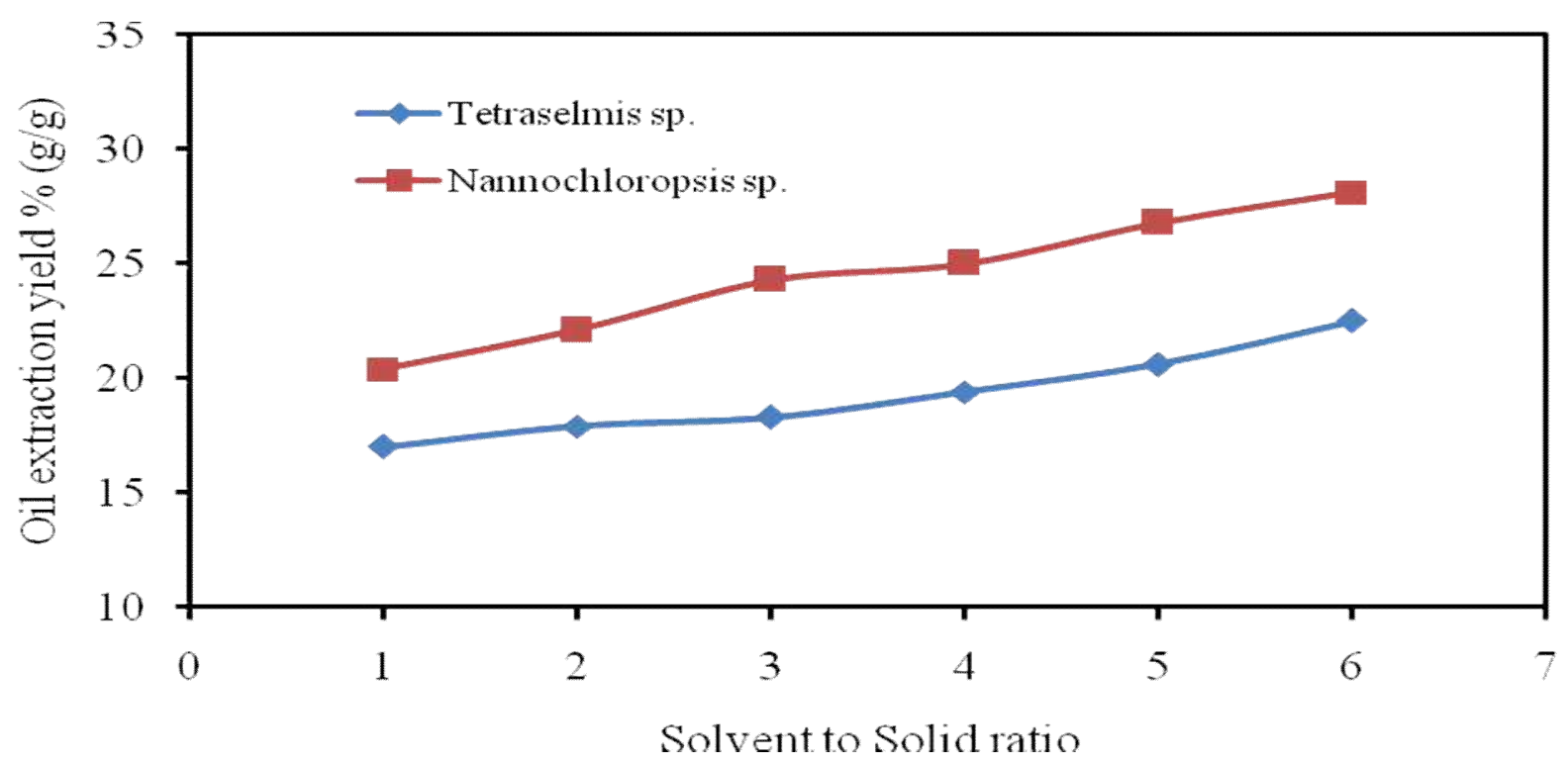

Figure 3. Effect of Solvent-to-Solid Ratio on Oil Extraction.

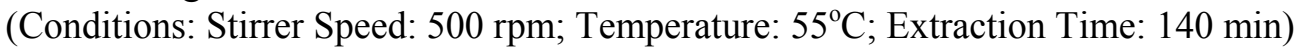


Table 2. Algaeoil Species Detected by GC-MS

\begin{tabular}{|c|c|c|c|c|c|}
\hline \multicolumn{3}{|c|}{ Nannochloropsis sp. } & \multicolumn{3}{|c|}{ Tetraselmis sp. } \\
\hline $\begin{array}{c}\mathrm{RT} \\
(\mathrm{min})\end{array}$ & Compound & $\begin{array}{c}\text { Area } \\
(\%)\end{array}$ & $\begin{array}{c}\mathrm{RT} \\
(\mathrm{min})\end{array}$ & Compound & $\begin{array}{c}\text { Area } \\
(\%)\end{array}$ \\
\hline 6.454 & 1-Decene & 1.39 & 5.244 & Pyrrole & 1.88 \\
\hline 8.185 & Undecane & 0.66 & 5.548 & Toluene & 2.9 \\
\hline 8.387 & Dimethoxymethylbenzene & 0.56 & 7.982 & Pyridine, 3-methyl- & 1.18 \\
\hline 9.581 & 1-Dodecene & 4.35 & 8.158 & 2-Furanmethanol & 1.14 \\
\hline 9.704 & Tetradecane & 0.74 & 12.411 & $\begin{array}{c}\text { 2,4-Dimethyl-2- } \\
\text { oxazoline-4-methanol }\end{array}$ & 1.62 \\
\hline 12.397 & 1-Pentadecene & 7.56 & 12.724 & Phenol & 1.54 \\
\hline 12.499 & pentadecane & 1.10 & 13.42 & $\begin{array}{l}\text { 1,2-Cyclopentanedione, } \\
\text { 3-methyl- }\end{array}$ & 1.41 \\
\hline 13.862 & N,N-Dimethyl-Heptylamine & 1.59 & 15.596 & $\begin{array}{l}\text { 2-Undecanone, } 6,10 \text { - } \\
\text { dimethyl- }\end{array}$ & 1.37 \\
\hline 13.944 & 2,4-Di-tert-butylphenol & 10.16 & 16.318 & Undecane & 1.18 \\
\hline 14.908 & 1-Pentadecene & 10.28 & 19.351 & $\begin{array}{l}\text { Benzene, }(2- \\
\text { methyloctyl)- }\end{array}$ & 1.45 \\
\hline 14.992 & 1-Bromo-2-methyldecane & 1.47 & 21.464 & Indolizine & 2.33 \\
\hline 16.147 & Nanodecane & 1.32 & 23.974 & Cyclododecane & 1.11 \\
\hline 16.253 & Di-methyldodecylamine & 1.06 & 24.604 & Heptadecane & 1.77 \\
\hline 17.165 & 1-Nonadecene & 10.11 & 24.857 & $\begin{array}{l}\text { 3,7,11,15-Tetramethyl- } \\
\text { 2-hexadecen-1-ol }\end{array}$ & 2.7 \\
\hline 17.668 & Neophytadiene & 1.54 & 26.944 & 3-Eicosyne & 1.24 \\
\hline 18.537 & Methyl Palmitate & 2.91 & 31.75 & Hexadecanenitrile & 3.83 \\
\hline 18.894 & Palmitic acid & 1.97 & 31.852 & 2-Heptadecanone & 3.46 \\
\hline 19.210 & 1-Nonadecene & 8.78 & 32.207 & $\begin{array}{l}\text { Hexadecanoic acid, } \\
\text { methyl ester }\end{array}$ & 0.77 \\
\hline 20.213 & Methyl linoleate & 12.07 & 32.308 & Hexadecenenitrile & 1.09 \\
\hline 20.448 & Methyl behenate & 1.37 & 32.562 & $\begin{array}{l}\text { 7-Octadecenoic acid, } \\
\text { methyl ester }\end{array}$ & 1.57 \\
\hline 21.077 & 1-Nanodecene & 5.96 & 34.115 & $\begin{array}{l}\text { 9-Octadecenoic acid (Z)- } \\
\text {, methyl ester }\end{array}$ & 0.64 \\
\hline 22.794 & 9-Hexacosene & 3.80 & 34.323 & Phytol & 2.73 \\
\hline 24.075 & Monoethylhexylphthalate & 3.05 & 34.385 & Hexadecanamide & 2.4 \\
\hline 24.384 & 9-Hexacosene & 2.36 & 34.962 & 9-Octadecenamide, $(\mathrm{Z})$ - & 1.97 \\
\hline
\end{tabular}




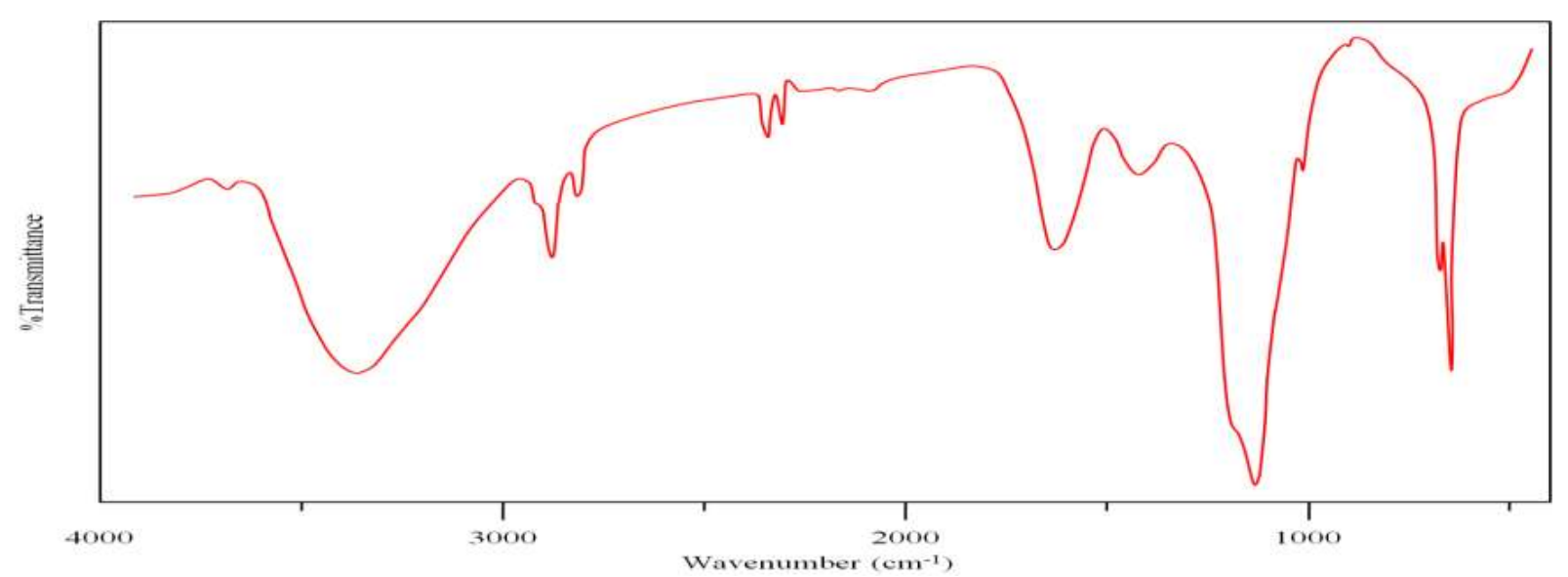

(a)

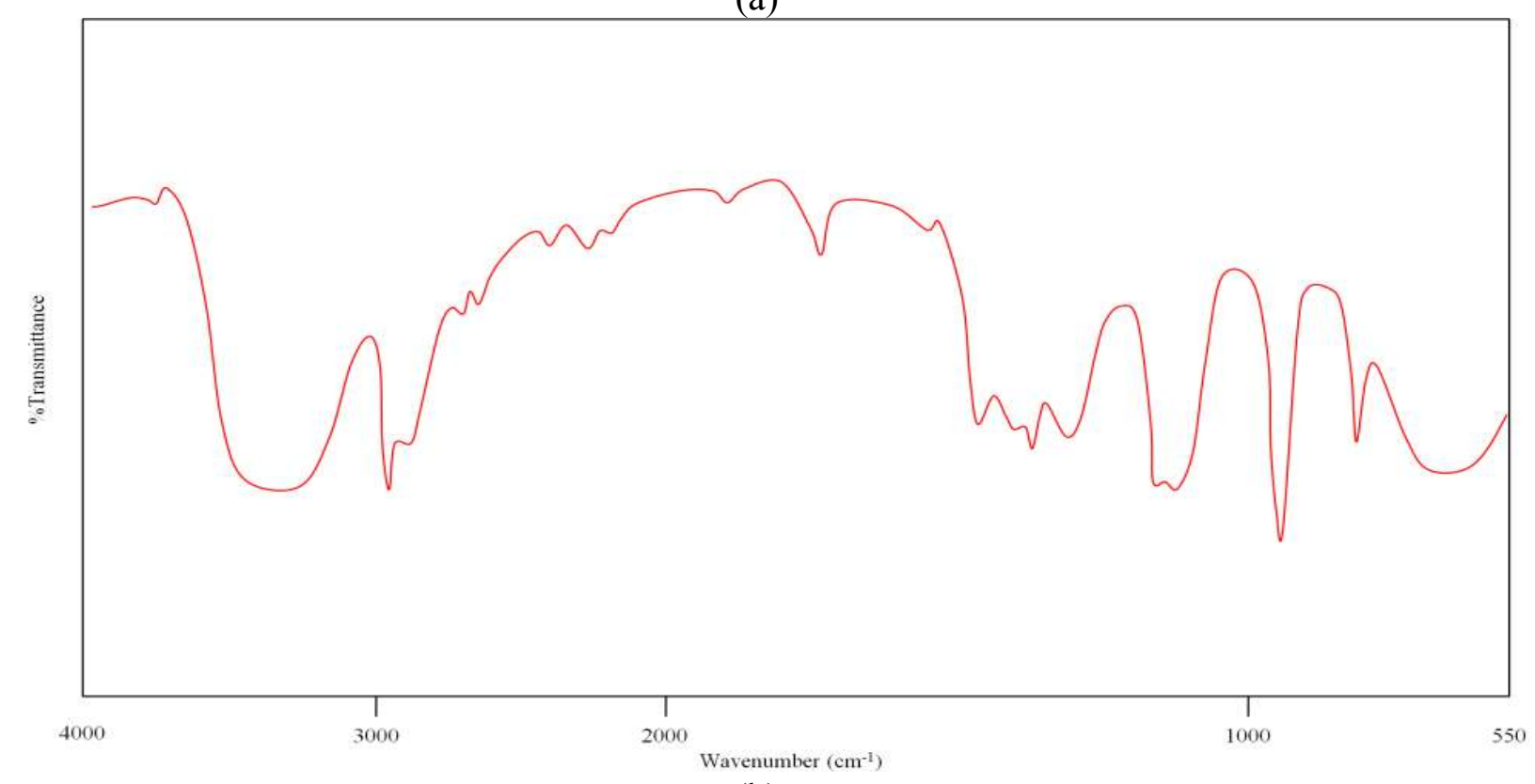

(b)

Figure 4. FTIR Spectra For Microalgae Oil: (a) Nannochloropsis sp., (b) Tetraselmis sp.

\section{CONCLUSIONS}

The conclusions for the extraction of oil from Nannochloropsis sp. and Tetraselmis sp. are listed as follows :

1. Temperature had effect on algae oil yield. As extraction temperature increased, algae oil yield rose.

2. Oil yield extracted was influenced by ratio of solvent to solid. Increasing of ratio solvent to solid would increase oil yield.

3. Oil yield influenced by extraction time which increase in extraction time would enhance oil yield.
4. Oil yieldwas also affected by extraction timeThe primary components of the oil from Nannochloropsis sp. are similar to those of the the oil from Tetraselmis sp.

5. From a GC-MS analysis, the main compounds of the algae oil are acids, alkanes, alkenes, amides, aldehydes, terpenes, pyrrolidinines, phytol and phenols.

\section{Acknowledgements}

This research was financially supported by the Directorate of Research and Community Service of the Directorate General Higher Education, The Ministry of Education and Culture, Republic of Indonesia. 


\section{REFERENCES}

Chisti, Y., 2007. Biodiesel from microalgae, Biotechnology Advances,25, 294306.

Metting, F. B., 1996. Biodiversity and application of microalgae. Journal of Industrial Microbiology,17, 477489.

Spolaore, P., Joannis-Cassan C., Duran E.\& Isambert A., 2006. Commercial application of microalgae, Journal of Bioscience and Bioengineering, 101, 87-96.

Nigam P.S. \& Singh A., 2010. Production of liquid biofuels from renewable resources, Progress in Energy and Combustion Science.

Li Y., Horsman M., Wu N., Lan C.Q.\& Dubois - Calero N., 2008. Biofuels from microalgae, Biotechnology Progress, 24, 815-820. 